\title{
The Effect of Motivation and Discipline on Employee Performance at the Ministry of Transportation's Directorate of Ports
}

\author{
Totong Endang $\mathrm{S}^{1}$, Elliana Sari ${ }^{2}$ \\ Institute of Social Sciences and Management Postgraduate Program of STIAMI Jakarta \\ Correspondent: totong_se@yahoo.com
}

Submitted: 5 August 2019. Revised: 25 August, 13 Sept 2019. Published: 30 October 2019.

\begin{abstract}
Motivation and work discipline are the important things in an organization, because theh are a factor which plays a role in obtaining the optimal work. With the motivation accompanied by good work discipline of the employees will greatly affect the personal performance which in the end the organizational goals will be easily achieved. This study aims to determine the effect of motivation and discipline on employee performance, both together and partially. The approach of this research is quantitative with a population of 149 and sample 108. Data collection using questionnaires and data analysis using $\mathrm{t}$ test and $\mathrm{F}$ test. The results showed motivation has an influence on the performance of the Directorate of Ports of the Ministry of Transportation's employees by $15.6 \%$. Discipline has an influence on the performance of the Ministry of Transportation's Port Directorate's employees by $19.4 \%$. Motivation and Discipline together have an influence of $27.6 \%$.
\end{abstract}

Keywords: Motivation, Discipline, and Employee Performance

\section{INTRODUCTION}

As seen throughout the history, the position and role of the State Civil Apparatus is important and decisive, because the Civil Servants are elements of the State Civil Apparatus to carry out government and development in order to achieve National goals. The National Goals can only be achieved through National Development which is planned in a directed and realistic manner and carried out in stages, in a serious, effective and effective manner. But researchers have failed to fully explore the extent to which two motivators (ie, public service motivation and mission valence) interact with these leadership practices to influence employee performance (Caillier, 2014).

The smooth running of the government and National Development mainly depends on the perfection of the State Civil Apparatus and the perfection of the State Civil Apparatus in essence depending on the perfection of the Civil Servants. Civil Servants are not only elements of the State Civil Apparatus but also are servants of the State and the people who live in the midst of the community and work for the interests of the community, therefore the position of the function and role of the State Civil Apparatus serving as a public servant must provide the best service to Public.

To be able to carry out their duties properly, employee coaching is directed to improve the quality of human resources (HR) in order to have attitudes and behaviors that have core services, honesty, responsibility, discipline and authority so that they can provide services in accordance with the demands of community development. 
The Directorate of Ports of the Ministry of Transportation has a role and task that is so heavy, so it requires human resources who have reliable performance. In improving the performance of the Ministry of Transportation's Port Directorate employees, discipline is an attitude / behavior or obedience, both to the applicable provisions and orders / instructions from superiors or leaders carried out consciously and with full responsibility. In other words discipline means obedience and obedience to all norms that apply in a particular environment which is a radiant of conscience based on national understanding and belief in the truth and usefulness of these norms.

If an employee's attitude is not good at work, then the person concerned certainly will not fulfill the desires that exist in him. This is already a law of nature, that no victory can be achieved without sacrifice and no sacrifice is in vain. This means that people who do not want to work will not get something, and people who are good at work, workmanlike and diligent in working will certainly get something in return from what they do.

Based on preliminary survey results, the achievement of the 2016 Ministry of Transportation's Port Directorate Performance targets has not shown encouraging results. This is proven by the fact that there are still performance targets that have not reached $100 \%$ of the targets set according to the Medium-Term Development Plan of the Directorate General of Sea Transportation, Ministry of Transportation for 2015-2019.

Table 1. The Performance Targets of the 2016 Directorate of Ports which have not been Achieved

\begin{tabular}{|c|c|c|c|c|c|c|}
\hline No & & Performance Indicator & Unit & $\begin{array}{c}\text { Target } \\
\text { (in million) }\end{array}$ & $\begin{array}{l}\text { Realization } \\
\text { (in Million) }\end{array}$ & $\begin{array}{l}\text { Performance } \\
(\%)\end{array}$ \\
\hline \multirow[t]{6}{*}{1} & \multicolumn{6}{|c|}{ The Increased Performance of the Directorate of Ports in Realizing Good Governance } \\
\hline & a. & Budget Absorption & $\%$ & 55 & 52,46 & 95 \\
\hline & b. & Value of State Property & $\mathrm{Rp}$ & 1.153 .874 & 485.951 & 42 \\
\hline & c. & $\begin{array}{l}\text { Approval for Development and } \\
\text { Operation of Pelum \& Tersus }\end{array}$ & Doc & 250 & 226 & 90,4 \\
\hline & d. & $\begin{array}{l}\text { Port Services managed through Port } \\
\text { Business Entity (BUP) }\end{array}$ & Doc & 5 & 4 & 80 \\
\hline & \multicolumn{6}{|c|}{ Increased Administrative and Technical Support } \\
\hline 2 & $\begin{array}{l}\text { Eva } \\
\text { guic }\end{array}$ & $\begin{array}{l}\text { luation / monitoring / } \\
\text { ance / socialization }\end{array}$ & Doc & 28 & 27 & 96 \\
\hline
\end{tabular}

Source: LAKIP Directorate of Ports 2016

Based on the above table, it can be seen that the performance objectives of the Directorate of Ports have not yet been achieved, reflecting the performance of employees at the Directorate of Ports which has not been satisfactory. Employee performance standards at the Directorate of Ports refer to Regulation of the Minister of Transportation Number PM 91 of 2013 concerning Procedures for Evaluating the Performance of Civil Servants in the Ministry of Transportation. Regulation of the Minister of Transportation Number PM. 189 of 2015 concerning the Organization and Work Procedure of the Ministry of Transportation as amended last PM. 117 of 2017, However, according to Minister of Transportation's Regulation PM Number 59 Year 2010 concerning the Office of the Ministry of Transportation Office Administration System, employee performance data (LP2P / DP3 / SKP) are technically included in the confidentiality level category, making it difficult to obtain data as evidence of actual performance conditions at Directorate of Ports.

With inaccuracies in completing work, not meeting work targets, often there are still employees coming late to work, there are employees being passive about work, and there are still 
some employees who leave work during working hours without valid information. Based on information obtained from the Directorate of Ports of the Ministry of Transportation, it is known that so far the decline in employee performance is caused by several factors presented in the table below:

Table 2. The Survey Results Regarding the Causes of the Declining Performance of the Ministry of Transportation's Port Directorate Employees

\begin{tabular}{clcc}
\hline No & $\begin{array}{c}\text { Factors Causing the Declining of } \\
\text { Employee Performance }\end{array}$ & $\begin{array}{c}\text { Number of } \\
\text { Answers }\end{array}$ & Percentage \\
\hline $\mathbf{1}$ & Inaccurate completion of the task & 7 & $35 \%$ \\
\hline $\mathbf{2}$ & Mismatched working hours & 6 & $30 \%$ \\
\hline $\mathbf{3}$ & Decreased attendance & 4 & $20 \%$ \\
\hline $\mathbf{4}$ & Lack of cooperation between employees & 3 & $15 \%$ \\
\hline \multicolumn{2}{c}{ Total } & $\mathbf{2 0}$ & $\mathbf{1 0 0} \%$
\end{tabular}

Source: Employee performance data (LP2P / DP3 / SKP) which are technically included in the confidentiality level category at the Directorate of Ports 2016

The survey results show 7 people $(35 \%)$ decreased employee performance due to inaccuracy in completing tasks, as many as 6 people $(30 \%)$ said that the decline in employee performance was due to incompatible working hours, where the frequent violations of work hours occurred. Meanwhile, as many as 4 people $(20 \%)$ said that the decline in employee performance was due to a decreased attendance rate, and as many as 3 people $(15 \%)$ said that the decline in employee performance was due to employees of the Ministry of Transportation's Directorate of Transportation not cooperating with other employees in completing work or an tasks determined by the agency.

The apparatus condition as explained above is assumed that the main cause of the decline in performance is motivation and work discipline. In theory, various definitions of motivation usually contain wants, hopes, needs, goals, objectives, encouragement and incentives. Thus a motive is a mental state that encourages, activates and moves and its motive that moves and channel a person's behavior, attitudes and actions that are always associated with the achievement of goals. Someone's impulse to work is influenced by the needs that must be met and the level of needs that are different for each employee, so that there can be differences in motivation and in achievement while taking into account the motivation of employees as individuals (Eisele, Grohnert, Beausaert, \& Segers, 2013).

Motivation in one's work is very influential on the performance that can be achieved in his work. Employee motivation is a factor that greatly influences performance (Manzoor, 2012: 3). An employee's behavior can change because of changes he experienced personally or organization. These changes can be fast or slow depending on the nature of the individual concerned. While changes in groups occur more slowly because they require a large enough force to be carried out and take place against group members in a high enough level of contribution. The relationship of motivation and performance at the organizational level is very dependent on motivation in management elements in all hierarchies that play a role in it.

Discipline is a management action to encourage members of the organization to meet the demands of various provisions. In other words employee discipline is a form of training that seeks to improve and shape knowledge, employee attitudes and behaviors so that the employee voluntarily tries to work cooperatively with other employees and improves his work performance.

Implement good discipline, directly or indirectly, can improve the performance of government officials. Sanctions given informally to undisciplined employees are more effective in 
reducing the level of "low performance" than sanctions imposed by management (Fitch and Ravlin, 2004: 6). But there are things that need to be considered, that to do something requires enthusiasm to motivate someone to do it. So far, many have become obstacles for the apparatus in carrying out their duties and functions, one of which is the lack of motivation at work.

Motivation and work discipline are very important factors to get maximum performance. When someone is motivated to form, then he will try as much as possible with all the ability he has to display the work assignments. In addition, the motivation felt by an employee will affect the work discipline in carrying out the task. Motivation and work discipline are important things in an organization, because this is a factor that plays a role in obtaining optimal work. With the motivation accompanied by good work discipline of the employees will greatly affect personal performance which in the end organizational goals will be easily achieved.

With high motivation and work discipline, the performance will also increase because employees feel cared for by their institutions. This is because every employee has the hope to have a better life in accordance with the sacrifices and responsibilities imposed by employees in carrying out their work. However, the performance of civil servants is still alarming. However, there are still many civil servants who have high discipline and motivation, are professional and have great pride in the predicate they hold as good civil servants (Hendriyaldi, 2017). There is no difference between the performance of employees who are permanent and outsourced employees, as well as those who have attended training and not participated in training, as well as length of service. Some things that receive attention are the amount of salary currently received, training and development standards in enhancing the skills of officers, monitoring attendance, implementing flight regulations, as well as providing bonuses / overtime pay and benefits in accordance with workload (Yuliana, 2017).

The results of previous studies state that discipline does not significantly influence motivation. The work environment has no significant effect on motivation. Cultural organizations do not have a significant influence on motivation. Competence does not have a significant effect on motivation. Discipline has no significant effect on job satisfaction. The work environment has a significant effect on job satisfaction. Cultural organizations do not have a significant influence on job satisfaction. Competence does not have a significant effect on job satisfaction. Discipline has a significant effect on employee performance. The work environment has no significant effect on employee performance. Cultural organizations have a significant influence on employee performance. Competence has a significant effect on employee performance. Job satisfaction has a significant effect on employee performance. Motivation has a significant effect on employee performance (Amiroso, 2015).

An understanding of public service motivation by clarifying the mechanisms through which public service motivation influences employee attitudes previously related to organizational performance. Caution must be exercised when making claims regarding the effects of public service motivation (Wright \& Pandey, 2008).

\section{METHOD}

Data collection in this study was conducted on primary data in the form of respondents' statements obtained from answers to the research questionnaire given by researchers to respondents containing structured statement items (alternative answers have been determined) for two independent variables and one dependent variable. The population of this study was 149 employees at the Ministry of Transportation's Port Directorate. The research sample is part of the 
total population determined in the research representative. The sampling technique uses accidental sampling, which is the sample taken at the time of the study. In determining the sample, the author uses the Slovin formula as a tool to calculate the sample size because the total population is known to be more than 100 respondents. The Slovin formula is as follows: (Slovin in Umar, 2004: 49).

$$
\mathrm{n}=\frac{\mathrm{N}}{1+\mathrm{N}(\mathrm{e})^{2}}
$$

Note: $\mathrm{n}=$ sample

$\mathrm{N}=$ Employee population

$\mathrm{e}=$ error $0.5 \%$

Known :

$$
\begin{aligned}
\mathrm{n} & = \\
& 1+149(0,05)^{2} \\
& =108 \text { Persons }
\end{aligned}
$$

\begin{tabular}{|c|c|c|}
\hline VARIABLE & DIMENTION & INDICATOR \\
\hline \multirow[t]{10}{*}{ Motivation $\left(\mathrm{X}_{1}\right)$} & \multirow[t]{5}{*}{ Work Condition } & A spacious workspace \\
\hline & & Ventilation \\
\hline & & work equipment \\
\hline & & rest area \\
\hline & & place of worship \\
\hline & \multirow[t]{2}{*}{ Discipline } & Objective \\
\hline & & Educating \\
\hline & \multirow[t]{3}{*}{ award } & Boss Attention \\
\hline & & Charter \\
\hline & & Present \\
\hline \multirow[t]{10}{*}{ Discipline $\left(\mathrm{X}_{2}\right)$} & \multirow[t]{2}{*}{ Attendance } & Om Time \\
\hline & & Attendance \\
\hline & \multirow[t]{2}{*}{ Work standards obedience } & Work standards according to rules \\
\hline & & Work standards according to guidelines \\
\hline & \multirow[t]{3}{*}{ Rules obedience } & Responsible \\
\hline & & Smooth carrying out tasks \\
\hline & & Don't leave work \\
\hline & \multirow[t]{3}{*}{ Work Ethics } & Build a harmonious atmosphere \\
\hline & & Mutual respect \\
\hline & & Help each other \\
\hline \multirow{10}{*}{$\begin{array}{l}\text { Employee } \\
\text { Performance (Y) }\end{array}$} & \multirow[t]{2}{*}{ Quality of work } & According to workload \\
\hline & & In accordance with SOP \\
\hline & \multirow[t]{2}{*}{ Punctuality } & On schedule \\
\hline & & On time \\
\hline & \multirow[t]{2}{*}{ Initiative } & Give an idea \\
\hline & & Make a breakthrough \\
\hline & \multirow[t]{2}{*}{ Ability } & Responsible \\
\hline & & Experienced \\
\hline & \multirow[t]{2}{*}{ Communication } & Horizontal \\
\hline & & Vertical \\
\hline
\end{tabular}

From the calculation results in the error stage of 5\%, then as many as 108 people will be taken.

Table 3. Variable Operational Definitions 


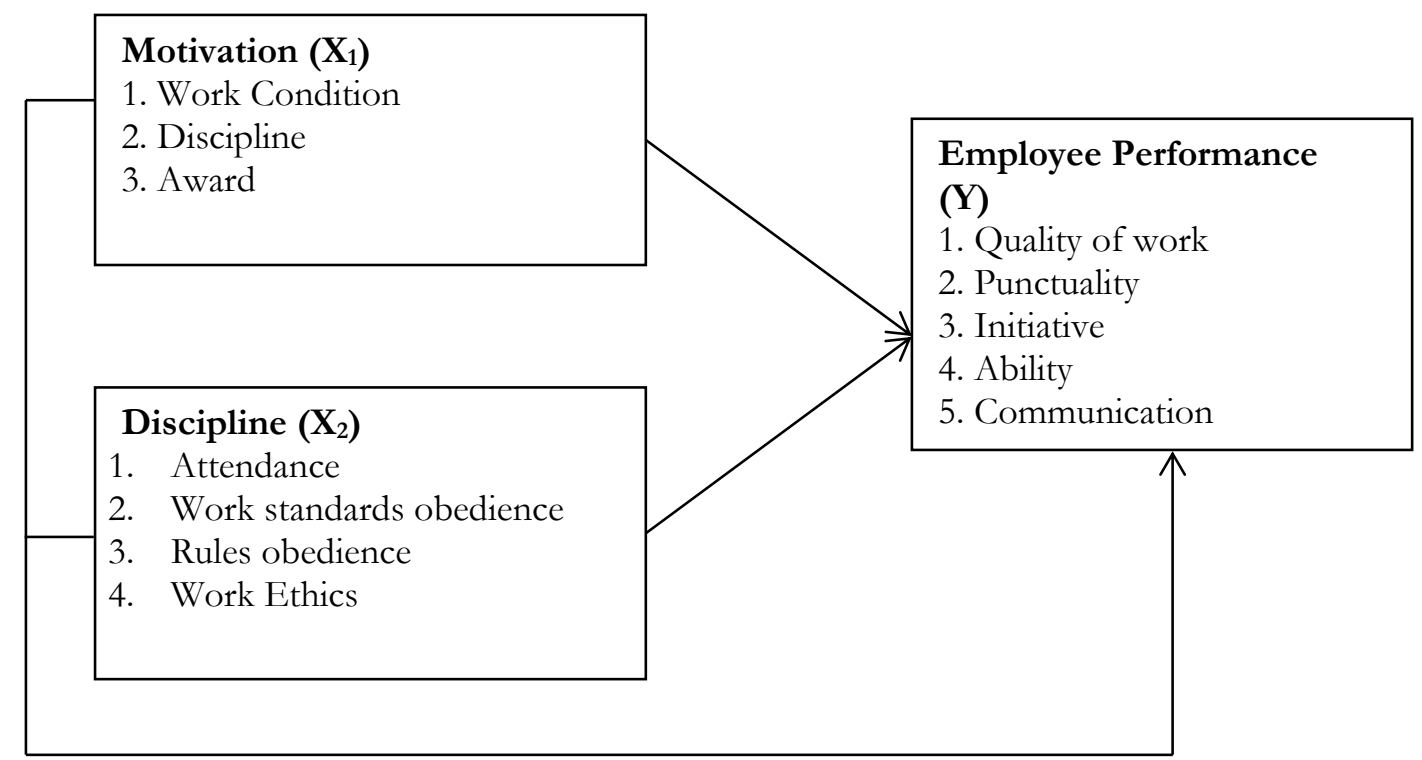

Figure 1. Conceptual Framework

The hypothesis is a temporary answer to the problem to be studied. Hypotheses are prepared and tested to show right or wrong by being free from the values and opinions of researchers who compile and test them. Then, the hypothesis in this study can be formulated as follows: (1) motivation has a positive and significant effect on employee performance; (2) discipline has a positive and significant effect on employee performance; and (3) motivation and discipline together have a positive and significant effect on employee performance.

\section{RESULT AND DISCUSSION}

Table 4. F-Test of The Effect of Motivation and Discipline Variables on Employee Performance

\begin{tabular}{|c|c|c|c|c|c|c|}
\hline \multicolumn{7}{|c|}{ ANOVA $^{a}$} \\
\hline \multicolumn{2}{|c|}{ Model } & \multirow{2}{*}{$\begin{array}{l}\text { Sum of } \\
\text { Squares } \\
137.568\end{array}$} & \multirow{2}{*}{$\begin{array}{l}\text { Df } \\
2 \\
2\end{array}$} & \multirow{2}{*}{$\begin{array}{l}\begin{array}{l}\text { Mean } \\
\text { Square } \\
68.784\end{array}\end{array}$} & \multirow{2}{*}{$\begin{array}{c}\mathrm{F} \\
19.995\end{array}$} & \multirow{2}{*}{$\begin{array}{l}\text { Sig. } \\
.000^{\mathrm{b}}\end{array}$} \\
\hline 1 & Regression & & & & & \\
\hline & Residual & 361.201 & 105 & 3.440 & & \\
\hline & Total & 498.769 & 107 & & & \\
\hline
\end{tabular}

a. Dependent Variable: Performance

b. Predictors: (Constant), Motivation, Discipline

From the significance value $\mathrm{F}$ is known as 0,000 which is smaller than 0.05 , or $\mathrm{F}$ is 19.995 greater than $\mathrm{F}_{\text {table }} 3.07$ with degrees of freedom $(\mathrm{df}=\mathrm{n}-\mathrm{k}-1=106)$ at $\mathrm{a}=0.05$. so $\mathrm{H}_{0}$ hypothesis was rejected and $\mathrm{H}_{a}$ hypothesis was accepted. This means that there is an influence of Motivation and Discipline on Employee Performance, and the influence is positive. So together motivation and Discipline variables have a positive effect on performance. To find out the regression equation between Motivation and Discipline on Employee Performance used multiple linear regression test. Based on the results of calculations using SPSS Version 23.0, the regression equation is known as follows: 
The Effect of Motivation and Discipline on Employee Performance at the Ministry of Transportation's Directorate of Ports Endang S,Sari

Table 5. Regression Coefficient Effect of Motivation and Discipline on Employee Performance

Coefficients $^{\mathrm{a}}$

\begin{tabular}{|c|c|c|c|c|c|c|}
\hline \multirow{2}{*}{\multicolumn{2}{|c|}{ Model }} & \multicolumn{2}{|c|}{$\begin{array}{c}\text { Unstandardized } \\
\text { Coefficients }\end{array}$} & \multirow{3}{*}{$\begin{array}{c}\text { Standardized } \\
\text { Coefficients } \\
\text { Beta }\end{array}$} & \multirow{3}{*}{$\begin{array}{l}\mathrm{t} \\
.946\end{array}$} & \multirow{3}{*}{$\begin{array}{l}\text { Sig. } \\
\\
.347\end{array}$} \\
\hline & & \multirow{2}{*}{$\begin{array}{l}\mathrm{B} \\
5.074\end{array}$} & \multirow{2}{*}{$\begin{array}{r}\text { Std. Error } \\
5.365\end{array}$} & & & \\
\hline 1 & (Constant) & & & & & \\
\hline & Motivation & .396 & .115 & .298 & 3.450 & .001 \\
\hline & Discipline & .504 & 121 & .360 & 4.173 & .000 \\
\hline
\end{tabular}

a. Dependent Variable: Performance

\section{The Effect of Motivation on Performance}

From the results of data analysis, the determination coefficient of the motivation influence on employee performance of the Directorate ministry of Ports of Transportation is $15.6 \%$ with a significance level of $0,000<0.05$, where $\mathrm{Hi}$ is accepted and $\mathrm{H}_{0}$ is rejected. This means that motivation affects the performance of the Ministry of Transportation's Port Directorate employees. Achievement motivation is an impetus in the characteristics of a person to do an activity or task as well as possible in order to achieve achievement with honors. Employee motivation is a factor that greatly influences performance (A. Manzoor, Awan, \& Mariam, 2012; Patmawati \& Realize, 2018). Where motivation has a significant influence on employee performance and direction is positive.

Motivation is an important variable, which is where motivation needs to get the most attention for the organization in improving the performance of its employees. Work motivation is the encouragement or enthusiasm that arises in a person or employee to do something or work, due to external stimulation both from superiors and the work environment, as well as the basis for meeting needs and satisfaction, and fulfilling responsibilities for tasks given and carried out in the organization. Employee motivation as a force that drives employees to achieve specific organizational goals and objectives (Q.-A. Manzoor, 2011; Shahzadi, Javed, Pirzada, Nasreen, \& Khanam, 2014).

\section{The Effect of Discipline on Performance}

From the results of the analysis of the data obtained the magnitude of the influence of discipline on the performance of the Directorate ministry of Ports of Transportation's employees was $19.4 \%$. The level of discipline's significance to the performance of the Ministry of Transportation's Port Directorate employees is $0,000<0.05$, so it can be concluded that the discipline of the Ministry of Transportation's Port Directorate employee performance is significantly. Sanctions that are given informally to undisciplined employees are more effective in reducing the level of "low performance" compared to sanctions given by management. Work discipline must be owned by every employee and must be cultivated among employees in order to support the achievement of organizational goals because it is a form of compliance with work rules and also as self responsibility to the organization. The implementation of discipline based on awareness and conviction will create a harmonious condition between desire and reality. To create this harmonious condition, harmony must be made between the obligations and the rights of employees. So it can be concluded that discipline is an attitude of loyalty and obedience of a person or group of people to the rules both written and unwritten, which is reflected in the form of 
behavior and deeds. This proves that employee discipline has an influence on employee performance (Amiroso, 2015; Patmawati \& Realize, 2018). Work discipline has a significant influence on employee performance and its positive direction.

\section{The Effect of Motivation and Discipline on Performance}

From the results of data analysis it is known that the Effect of Motivation and Discipline on the Performance of the Directorate of Ports of the Ministry of Transportation's Employees is 27.6\%. The Influence of Motivation and Discipline on Employee Performance of the Directorate of Ports of the Ministry of Transportation is significant because the significance value of $\mathrm{F}$ is 0,000 $<0.05$.

\section{CONCLUSION}

Motivation has a positive and significant effect on employee performance of $15.6 \%$, in other words the stronger the motivation of employees, the more the employee performance of the Directorate of Ports of the Ministry of Transportation increases. Discipline has a positive and significant effect on employee performance by $19.6 \%$. In other words, the higher the level of employee discipline, the more the performance of the Directorate of Port of the Ministry of Transportation employees will increase. Motivation and discipline have a positive and significant effect on employee performance by $27.6 \%$. In other words, the stronger the motivation and discipline, the better the performance of the Ministry of Transportation's Port Directorate employees will improve.

In an effort to increase motivation, by giving the best to employees in work, such as promotions, career paths, promotions, opportunities for education. Thus employees in their work will act professionally because what they do will be rewarded in accordance with the outcomes provided and the better the outcomes produced, the wider the opportunities for a career and reach a better position that will directly improve the quality of life for their families to be able to decent life. Increasing motivation includes the need for better responsibilities and encouragement, discipline of obedience to work regulations, awareness of work ethics, work quality and effectiveness of work independence by conducting intense supervision and the leadership must act decisively and be fair in giving punishment. Stricter law enforcement is needed for administrative discipline of employee discipline where it is not only limited to the enforcement of working hours but also about performance is needed. Further research needs to be done related to motivation and discipline on employee performance including work quality, timeliness, initiative, ability and communication outside of motivation and discipline factors.

\section{REFERENCE}

Amiroso, J. M. (2015). Influence of Discipline, Working Environment, Culture of Organization and Competence on Workers' Performance through Motivation, Job Satisfaction (Study in Regional Development Planning Board of Sukoharjo Regency). European Journal of Business and Management. https://doi.org/ISSN 2222-1905 (Paper) ISSN 2222-2839

Caillier, J. G. (2014). Toward a better understanding of the relationship between transformational leadership, public service motivation, mission valence, and employee performance: A preliminary study. Public Personnel Management, 43(2), 218-239. https://doi.org/10.1177/0091026014528478

Eisele, L., Grohnert, T., Beausaert, S., \& Segers, M. (2013). Employee motivation for personal 
development plan effectiveness. European Journal of Training and Development, 37(6), 527-543. https://doi.org/10.1108/EJTD-02-2013-0015

Hendriyaldi. (2017). Pengaruh Motivasi Dan Disiplin Kerja Terhadap Kinerja Pegawai Direktorat Jenderal Perhubungan Darat Kementerian Perhubungan. Jurnal Ilmiah Universitas Batanghari, 17(2), 146-157. Retrieved from http://ji.unbari.ac.id/index.php/ilmiah/article/view/367/357

Manzoor, A., Awan, H., \& Mariam, S. (2012). Investigating the Ipact of Work Stress on Job Performance: A Study on Textile Sector of Faisalabad. Asian Journal of Business and Management Sciences, 2(1), 20-28. Retrieved from http://www.ajbms.org/articlepdf/3ajbms20121121721.pdf

Manzoor, Q.-A. (2011). Impact of Employees Motivation on Organizational Effectiveness. Business Management and Strategy, 3(1), 1-12. https://doi.org/10.5296/bms.v3i1.904

Patmawati, D., \& Realize, R. (2018). The Effect Of Motivation And Discipline Toward Performance of Employee on PT Sempurna Readymix Concrete. Jurnal Apresiasi Ekonomi, 6(2), 133-142. https://doi.org/10.31846/jae.v6i2.74

Shahzadi, I., Javed, A., Pirzada, S. S., Nasreen, S., \& Khanam, F. (2014). Impact of Employee Motivation on Employee Performance. European Journal of Business and ManagementOnline), 6(23), 2222-2839. Retrieved from https://pdfs.semanticscholar.org/4cbe/a9607d00a242b54a4bc9270b74352038e40f.pdf

Wright, B. E., \& Pandey, S. K. (2008). Public service motivation and the assumption of personorganization fit: Testing the mediating effect of value congruence. Administration and Society, 40(5), 502-521. https://doi.org/10.1177/0095399708320187

Yuliana, D. (2017). Faktor-Faktor yang Mempengaruhi Kinerja Personel Ground Handling PT. Jasa Angkasa Semesta (PT. JAS) di Bandara Halim Perdana Kusuma - Jakarta. Warta Penelitian Perbubungan. https://doi.org/10.25104/warlit.v29i1.267 